\title{
Front Matter: Volume 11634
}

, "Front Matter: Volume 11634," Proc. SPIE 11634, Multimodal Biomedical Imaging XVI, 1163401 (1 April 2021); doi: 10.1117/12.2596553

SPIE. Event: SPIE BiOS, 2021, Online Only 


\section{PROGRESS IN BIOMEDICAL OPTICS AND IMAGING}

\section{Multimodal Biomedical Imaging XVI}

Fred S. Azar

Xavier Intes

Qianqian Fang

Editors

6-11 March 2021

Online Only, United States

Sponsored and Published by

SPIE 
The papers in this volume were part of the technical conference cited on the cover and title page. Papers were selected and subject to review by the editors and conference program committee. Some conference presentations may not be available for publication. Additional papers and presentation recordings may be available online in the SPIE Digital Library at SPIEDigitalLibrary.org.

The papers reflect the work and thoughts of the authors and are published herein as submitted. The publisher is not responsible for the validity of the information or for any outcomes resulting from reliance thereon.

Please use the following format to cite material from these proceedings:

Author(s), "Title of Paper," in Multimodal Biomedical Imaging XVI, edited by Fred S. Azar, Xavier Intes, Qianqian Fang, Proceedings of SPIE Vol. 11634 (SPIE, Bellingham, WA, 2021) Seven-digit Article CID Number.

ISSN: 1605-7422

ISSN: 2410-9045 (electronic)

ISBN: 9781510641037

ISBN: 9781510641044 (electronic)

Published by

SPIE

P.O. Box 10, Bellingham, Washington 98227-0010 USA

Telephone +1 3606763290 (Pacific Time) · Fax +1 3606471445

SPIE.org

Copyright (c) 2021, Society of Photo-Optical Instrumentation Engineers.

Copying of material in this book for internal or personal use, or for the internal or personal use of specific clients, beyond the fair use provisions granted by the U.S. Copyright Law is authorized by SPIE subject to payment of copying fees. The Transactional Reporting Service base fee for this volume is $\$ 21.00$ per article (or portion thereof), which should be paid directly to the Copyright Clearance Center (CCC), 222 Rosewood Drive, Danvers, MA 01923. Payment may also be made electronically through CCC Online at copyright.com. Other copying for republication, resale, advertising or promotion, or any form of systematic or multiple reproduction of any material in this book is prohibited except with permission in writing from the publisher. The CCC fee code is $1605-$ $7422 / 21 / \$ 21.00$.

Printed in the United States of America by Curran Associates, Inc., under license from SPIE.

Publication of record for individual papers is online in the SPIE Digital Library.

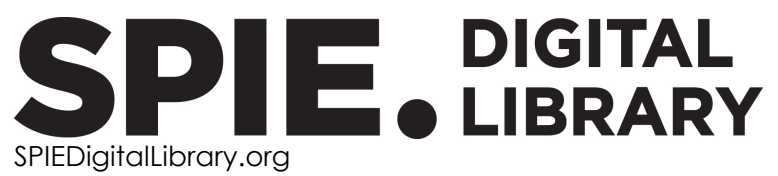

Paper Numbering: Proceedings of SPIE follow an e-First publication model. A unique citation identifier (CID) number is assigned to each article at the time of publication. Utilization of CIDs allows articles to be fully citable as soon as they are published online, and connects the same identifier to all online and print versions of the publication. SPIE uses a seven-digit CID article numbering system structured as follows:

- The first five digits correspond to the SPIE volume number.

- The last two digits indicate publication order within the volume using a Base 36 numbering system employing both numerals and letters. These two-number sets start with $00,01,02,03,04$, 05, 06, 07, 08, 09, 0A, OB ... 0Z, followed by 10-1Z, 20-2Z, etc. The CID Number appears on each page of the manuscript. 


\section{Contents}

\section{MACHINE LEARNING}

$11634 \mathrm{OE}$ Predicting geographic atrophy growth rate from fundus autofluorescence images using deep neural networks [11634-13]

MICROSCOPY AND SURGERY GUIDANCE

11634 OK Combining diffuse reflectance spectroscopy and ultrasound imaging for resection margin assessment during colorectal cancer surgery [11634-19]

$11634 \mathrm{OL} \quad$ Interleaving optical coherence microscopy with dual-channel fluorescence microscopy for simultaneous co-registration of structural and functional information [1 1634-20]

\section{POSTER SESSION}

11634 OM Three-dimensional imaging of bladder cancer using optical coherence tomography and fluorescence laminar optical tomography [1 1634-3]

$11634 \mathrm{ON} \quad$ Numerical study of the interaction of photons with mouse brain based on Monte Carlo method [11634-21]

11634 OP Transfer and deep learning techniques for the automatic diagnosis of COVID-19 respiratory diseases [11634-23]

$11634 \mathrm{OQ}$ A co-registered multimodal imaging system for reflectance, multiphoton, and optical coherence microscopy [11634-24]

11634 OR Transfer learning methods for classification of COVID-19 chest x-ray images [11634-25]

11634 OT Synthetic large volumetric optical-resolution photoacoustic microscopy using morphological pyramid fusion [11634-27]

11634 OU Image guiding system of high-resolution full field OCT [1 1634-28] 
Proc. of SPIE Vol. 11634 1163401-4

\section{Downloaded From: https://www.spiedigitallibrary.org/conference-proceedings-of-spie on 26 Apr 2023
Terms of Use: https://www.spiedigitallibrary.org/terms-of-use}

